\title{
Awareness and Use of Social Media by Undergraduates of Selected Universities in a State in Nigeria
}

\author{
Bosede A. Ajiboye (PhD)*, Olubunmi R. Adekonojo (Mrs.) and Timothy D. Adekonojo (Mr.) \\ Federal University of Agriculture, Nigeria \\ * E-mail of the corresponding author: ajiboyeba@funaab.edu.ng
}

\begin{abstract}
The purpose of this study is to explore undergraduates' awareness and usage of social media. A descriptive survey design was adopted with the use of questionnaire as the instrument for data collection. One thousand, one hundred and ninety-two $(1,192)$ copies of the questionnaire were administered on the students, out of which one thousand, one hundred and eight $(1,108)$ useable copies were retrieved, representing $93 \%$ response rate. The data were analysed using frequency counts, percentages and means. The results revealed that the respondents were aware of almost all listed social media platforms, with WhatsApp (99\%) ranking highest, followed by Email (97.9\%) and Twitter (95.3\%). The frequently utilised social media platforms were WhatsApp $(\overline{\mathrm{x}}=2.72)$, Email $(\overline{\mathrm{x}}=2.61)$ and Facebook $(\overline{\mathrm{x}}=2.50)$. These platforms were mainly used for group discussions and tutorials with course mates; this gave a mean score of $(\overline{\mathrm{x}}=3.22)$; for sourcing current materials gave a mean score of $(\overline{\mathrm{x}}=3.21)$, and checking updates on current research gave a mean score $(\overline{\mathrm{x}}=3.18)$. The study concluded that social networking is not new to most undergraduates and that they use social media for academic purposes, self-expression and for establishing friendships with fellow students around the globe. It was recommended, among other things, that students should be aware of the fact that overindulgence in social media is addictive and time-wasting; moreover, lecturers should assist students in making more meaningful use of the social media by incorporating it into their academic work.

Keywords: Social media, Uses and Gratification Theory, usage of social media, undergraduates

DOI: $10.7176 / \mathrm{IKM} / 12-2-01$
\end{abstract}

Publication date: February $28^{\text {th }} 2022$

\section{Introduction}

New technologies have radically changed the way people communicate (Adebayo 2015 and Balaban-Sali, 2012). With the ubiquity of platforms like WhatsApp, Facebook, Twitter, Myspace, Skype, LinkedIn and the likes, social media is gradually becoming an indispensable part of people's lives. They are used to communicate, read, comment, share, like, and create contents (Chen and Sakamato, 2013; Ma et al., 2014). These platforms are gaining popularity, and an increasing number of young people (Pempek et al. 2009), especially students, now comprise the highest percentage of social media users (Lewis, 2009; Sponcil and Gitimu 2013; Yoo and Kim, 2013). The young people make use of social media primarily to meet their information needs (Rubina and Shakeel, 2012).

Mozee (2012) has outlined the benefits of using the social media to include, encouragement of greater social interaction via electronic platforms; provision of greater access to information and information sources; encouragement of creativity amongst and between individuals and groups; it also creates a sense of belonging among users of common social media tools, and they increases the technology competence levels of frequent users.

Social media have a significant influence on the academic performance of undergraduate students, and their qualitative impact is determined by the type of usage (Mehmood and Taswir, 2013; Ahmed and Qazi, 2011). Students often times find it difficult to concentrate and study effectively because of the time spent on social networking sites. Quan-Haase and Young (2010) found that a majority of college students login into Facebook several times a day. Younger students tended to use Facebook more frequently than older students to keep in touch with friends from high school or from their hometown (Pempeket al., 2009). This kind of activityhas been found to causedistraction during instructional time, resulting in a tangible negative impact on learning (Flad, 2010). Thus, it is essential to determine the intensity and current trends of social networking among students, an objective for which we'll explore the types of social networks of which undergraduatesare cognizant as well asthe frequency of use.

\section{Statement of the Problem}

In Nigeria, students' current unwillingness to read comprehensively is considered exceptionally worrisome by many educators. It has been observed that students' reading culture has been impeded by various factors, resulting in a distinct plunge in levels of literacy. Many place most of the blame regarding falling standards of education on the persistent use of social media. Furthermore, it has been observed that undergraduates spend an inordinate amount of time in front of screens and on social media platforms, which they access on their laptops, desktops, cable television, palmtops, iPods, GSM Phones, smart phones, smart television, etc. Many choose to spend their time chatting with friends instead of reading. Even when some students use social media for academic purposes, they do so because it allows them to quickly lift answers for their assignments. Despite the abundant research and 
analysis that scrutinises social media usage, not much of it centres on undergraduates in Nigeria, specifically in Ogun State. Hence, this study was undertaken to examine the awareness and the usae of social media by undergraduates in selected universities in Ogun State, Nigeria.

\section{Research Questions}

1. What are the demographic characteristics of the undergraduates in the selected universities?

2. To what extent are the undergraduates in the selected universities aware of social media?

3 . How frequent do undergraduates in the selected universities use social media?

4. For what purposes do the undergraduates in the selected universities use social media?

\section{Objectives of the Study}

The objectives of this study are to:

1. describe the demographic characteristics of the undergraduates of selected universities

2. determine the extent of awareness of social media by the undergraduates' of selected universities

3. examine the frequency of use of social media by undergraduates' of selected universities

4. identify the purpose of use of social media by undergraduates' of selected universities

\section{Theoretical Framework and Review of Related Literature}

As this study is based on the undergraduates' awareness and usage of social media, the Uses and Gratifications Theory (U\&G) of Katz et al. 1974 is employed, as it provides a systematic explanation of why people use and access media programmes. This theory refines the conceptual conversation, allows for a cogent and methodical identification of the critical pieces needed in data collection, and points the way to the most efficient method of analysis.Furthermore, it is not passive and does not admit contents at face value, requiring the scrutiny of key terms in the data that are groundedupon personal, social, cultural, and emotional considerations: these are instrumental in guiding people in what they choose to consume from the media.

\section{Social Media}

According to Langat (2015), social media is the interactive communication that exists between people using a specialized electronic platform such as Facebook, WhatsApp, Twitter, Myspace, Linkedin and Instagram. These provide a means that allows them to create and share content (Lewis, 2009).Scholars observe that social media facilitates the growth of interactive dialogue and communities of users, regardless of their physical location;notably, academic libraries market their products and services on social media and make users aware of what goes on in the library, providing useful information that is accessed by online users in the social network space. Social media involves technology, social interaction and the coordination of ideas for creative and scientific innovation. This interaction and the manner in which information is presented allow for the integration ofdiverse perspectives, as people share information freely andconfer and interact with others. Through websites, individuals can create, share, connect and exchange ideas and opinions with one another and engage in person to person conversation.

\section{Use of Social Media}

Social media allow people to easily create their own online profile and display an online network of friends. Lenhart et al (2010) observed that about 57\% of social media users are 18-29 years old and have a personal profile on multiple social media websites. More than $50 \%$ of college students access a social networking site several times a day (Sheldon, 2008). Eberhardt (2007) opined that the culture of the student's environment is lately more socially oriented because of the emergence of online technologies. Students can use social media platforms tools to connect with other classrooms, track a word or phrase, attend lectures remotely, learn personal responsibility, find scientific research papers, create apps, classmate connections, provide direct communication with instructors, brainstorm, and knowledge-sharing among others. Mehmood (2013) stated that students are positively affected by the informative use of the social media while at the same time there can be a drastic impact on recreational use of social media on them.

\section{Methodology}

The descriptive survey design was adopted for the study. The population is made up of undergraduates of selected public and private universities in Ogun State, Nigeria, who were in their second to fifth years of study. A multistage sampling technique was used, with ten percent $(10 \%)$ of the total population $(11,919)$ of the undergraduates in the three faculties/schools selected; this was to ensure a fair representation of the entire population. The study was carried out towards the close of 2017/2018 academic session. The only instrument used for data collection was the questionnaire which contained close-ended items. One thousand, one hundred and eight (1108) copies of the questionnaire were retrieved and found usable. This figure represents $93 \%$ rate of return. Frequency count, 
percentages and mean were used to analyse the data.

Results and Discussions

Table 1: Gender of Respondents

\begin{tabular}{lll}
\hline Sex & Frequency & Percentage \\
\hline Male & 547 & 49 \\
Female & 561 & 51 \\
Total & 1108 & 100 \\
\hline
\end{tabular}

The gender of the respondents as presented in table 1 shows that there were more female undergraduates 561 $(51 \%)$ than the males $547(49 \%)$ in the institutions examined.

Table 2: Respondents' awareness of social media platforms

\begin{tabular}{llllll}
\hline S/N & Social Media & Frequency & Percentage & $\overline{\boldsymbol{x}}$ & S.D \\
\hline 1. & WhatsApp & 1097 & 99.0 & 1.008 & 0.303 \\
2. & Email & 1085 & 97.9 & 1.029 & 0.309 \\
3. & Twitter & 1056 & 95.3 & 1.069 & 0.032 \\
4. & Google+ & 1042 & 94.0 & 1.197 & 0.036 \\
5. & Instagram & 1035 & 93.4 & 1.201 & 0.036 \\
6. & Facebook & 1033 & 93.2 & 1.313 & 0.037 \\
7. & Youtube & 1026 & 92.6 & 1.412 & 0.040 \\
8. & Snapchat & 1016 & 91.7 & 1.537 & 0.046 \\
9. & BBM & 993 & 89.6 & 1.583 & 0.048 \\
10. & Blog & 900 & 81.2 & 1.690 & 0.051 \\
11. & LinkedIn & 452 & 40.8 & 1.779 & 0.053 \\
12. & Myspace & 356 & 32.1 & 1.807 & 0.054 \\
13. & Flickr & 318 & 28.7 & 1.848 & 0.056 \\
14. & Friendstar & 292 & 26.4 & 1.915 & 0.058 \\
\hline
\end{tabular}

Weighted mean $=1.44$

The result in Table 2 reveals that all respondents representing 100\% responded affirmatively, which indicates that they are aware of almost all social media platforms with WhatsApp ranking highest with a percentage of 99.0 followed by Email (97.9\%); Twitter (95.3\%) and the least was Flickr (28.7\%) and Friendstar (26.4\%) respectively. The inference drawn from this is that social media is not a new thing to most students in this era.

\section{Table 3: Usage of Social Media}

\begin{tabular}{|c|c|c|c|c|c|c|}
\hline $\mathbf{S} / \mathbf{N}$ & Social Media & Always & Occasionally & Never & $\bar{x}$ & S.D \\
\hline 1. & WhatsApp & $852(76.9)$ & $194(17.5)$ & $62(5.6)$ & 2.72 & 0.571 \\
\hline 2. & Email & 727 (65.6) & $312(28.2)$ & $69(6.2)$ & 2.61 & 0.632 \\
\hline 3. & Facebook & $637(57.5)$ & $370(33.4)$ & $101(9.1)$ & 2.50 & 0.864 \\
\hline 4. & Youtube & $624(56.3)$ & $397(35.8)$ & 87 (7.9) & 2.48 & 0.646 \\
\hline 5. & Instagram & $490(44.2)$ & $430(38.8)$ & $188(17)$ & 2.26 & 0.735 \\
\hline 6. & Google+ & 409 (36.9) & $557(50.3)$ & $142(12.8)$ & 2.25 & 0.669 \\
\hline 7. & Twitter & $481(43.4)$ & $412(37.2)$ & 215 (19.4) & 2.23 & 0.757 \\
\hline 8. & Snapchat & $418(37.7)$ & $381(34.4)$ & 309 (27.9) & 2.08 & 0.803 \\
\hline 9. & Blog & $152(13.7)$ & $524(47.3)$ & 432 (39) & 1.75 & 0.689 \\
\hline 10 . & BBM & $141(12.7)$ & $462(42.1)$ & $500(45.1)$ & 1.69 & 0.692 \\
\hline 11. & LinkedIn & $105(9.5)$ & $266(24)$ & $737(66.5)$ & 1.44 & 0.663 \\
\hline 12. & Myspace & $95(8.6)$ & $175(15.8)$ & 838 (75.6) & 1.34 & 0.636 \\
\hline 13. & Flickr & $83(7.5)$ & $167(15.1)$ & 858 (77.4) & 1.31 & 0.606 \\
\hline 14. & Friendstar & $86(7.8)$ & $153(13.8)$ & 869 (78.4) & 1.30 & 0.613 \\
\hline
\end{tabular}

Weighted mean $=1.90$

Table 3 indicates the frequently used social media platforms by the respondents. The frequently used were WhatsApp $(\bar{x}=2.72)$, Email $(\bar{x}=2.61)$ and Facebook $(\bar{x}=2.50)$ while the least used were Flickr $(\bar{x}=1.31)$ and Friendstar $(\bar{x}=1.30)$ indicated as being used by the respondents. The inference drawn from this is that, WhatsApp, Email and Facebook were the major social media being used by the undergraduates. This was because they were the social media platforms that ranked above the weighted mean of 1.90 set for the social usage. 
Table 4: Respondents' Purpose of Utilising Social Media

\begin{tabular}{|c|c|c|c|c|c|c|}
\hline Utilization of social media & Always & Occasionally & Seldom & Never & $\bar{x}$ & S.D \\
\hline $\begin{array}{l}\text { I use social media for group } \\
\text { discussions and tutorials with } \\
\text { course/classmates }\end{array}$ & $575(51.9)$ & $322(29.1)$ & $105(9.5)$ & $106(9.6)$ & 3.22 & 0.974 \\
\hline $\begin{array}{l}\text { Sourcing for materials to read for } \\
\text { examination and tests }\end{array}$ & $488(44)$ & $420(37.9)$ & $118(10.6)$ & $82(7.4)$ & 3.21 & 1.504 \\
\hline $\begin{array}{l}\text { Check updates on current research } \\
\text { or new developments in my field } \\
\text { of study }\end{array}$ & $482(43.5)$ & $418(37.7)$ & $143(12.9)$ & $65(5.9)$ & 3.18 & 0.875 \\
\hline $\begin{array}{l}\text { I use social media for finding and } \\
\text { chatting with friends online }\end{array}$ & $546(49.3)$ & $329(29.7)$ & $112(10.1)$ & $121(10.9)$ & 3.16 & 1.003 \\
\hline $\begin{array}{l}\text { Group socialization with peers, } \\
\text { relating to issues like politics, } \\
\text { education and religious matters. }\end{array}$ & $422(38.1)$ & $493(44.4)$ & $126(11.4)$ & $68(6.1)$ & 3.15 & 0.856 \\
\hline $\begin{array}{l}\text { To share and exchange academic } \\
\text { information }\end{array}$ & $490(44.2)$ & 387 (34.9) & $142(12.8)$ & $89(8)$ & 3.14 & 0.933 \\
\hline $\begin{array}{l}\text { To source for current information } \\
\text { on my course }\end{array}$ & $472(42.6)$ & $327(29.5)$ & $216(19.5)$ & $93(8.4)$ & 3.08 & 1.555 \\
\hline $\begin{array}{l}\text { Checking, reading and sending e- } \\
\text { mails }\end{array}$ & $474(42.8)$ & $360(32.5)$ & $115(10.4)$ & 159 (14.4) & 3.02 & 1.053 \\
\hline $\begin{array}{l}\text { Research activities such as finding } \\
\text { journal articles or publications }\end{array}$ & $285(25.7)$ & $573(51.7)$ & $143(12.9)$ & $107(9.7)$ & 3.00 & 1.745 \\
\hline $\begin{array}{l}\text { Downloading scholarly articles for } \\
\text { assignment or term papers }\end{array}$ & $344(31)$ & $467(42.1)$ & $220(19.9)$ & $77(6.9)$ & 2.97 & 0.893 \\
\hline $\begin{array}{l}\text { To get relevant information related } \\
\text { to my research or project work }\end{array}$ & 27.5) & 5.3) & $8.1)$ & $100(9)$ & 2.91 & 0.910 \\
\hline $\begin{array}{l}\text { Online learning and web-seminars } \\
\text { (webinars) }\end{array}$ & $339(30.6)$ & 405 (36.6) & $248(22.4)$ & $116(10.5)$ & 2.89 & 1.163 \\
\hline $\begin{array}{l}\begin{array}{l}\text { To search for information on } \\
\text { scholarship }\end{array} \\
\end{array}$ & $272(24.5)$ & $544(49.1)$ & $175(15.8)$ & $117(10.6)$ & 2.87 & 0.908 \\
\hline $\begin{array}{ll}\text { Reading of newspapers and } \\
\text { magazines on-line }\end{array}$ & $346(31.2)$ & $412(37.2)$ & $171(15.4)$ & $179(16.2)$ & 2.83 & 1.051 \\
\hline Photo sharing & $337(30.4)$ & $402(36.3)$ & $144(13)$ & $225(20.3)$ & 2.77 & 1.142 \\
\hline $\begin{array}{l}\text { To follow and learn from people } \\
\text { who have made their marks in my } \\
\text { chosen course/desired career }\end{array}$ & $253(22.8)$ & $411(37.1)$ & $275(24.8)$ & $169(15.3)$ & 2.67 & 0.998 \\
\hline $\begin{array}{l}\text { To create groups of likeminded } \\
\text { individuals }\end{array}$ & $227(20.5)$ & 479 (43.2) & $165(14.9)$ & $237(21.4)$ & 2.66 & 1.562 \\
\hline $\begin{array}{l}\text { To buy books or other information } \\
\text { materials online }\end{array}$ & $262(23.6)$ & $397(35.8)$ & $259(23.4)$ & $190(17.1)$ & 2.65 & 1.028 \\
\hline Sharing of business or vocational ideas & $206(18.6)$ & $484(43.7)$ & $188(17)$ & $230(20.8)$ & 2.59 & 1.021 \\
\hline Sports and entertainment news & $284(25.6)$ & $325(29.3)$ & $193(17.4)$ & $306(27.6)$ & 2.52 & 1.155 \\
\hline $\begin{array}{l}\text { To enroll for online certificates or } \\
\text { professional training. }\end{array}$ & $195(17.6)$ & $367(33.1)$ & $248(22.4)$ & 298 (26.9) & 2.40 & 1.071 \\
\hline Online shopping & $171(15.4)$ & $378(34.1)$ & $241(21.8)$ & $318(28.7)$ & 2.37 & 1.217 \\
\hline Marketing my products & $263(23.7)$ & $253(22.8)$ & $179(16.2)$ & $413(37.3)$ & 2.36 & 1.233 \\
\hline To publish my blog & $190(17.1)$ & $294(26.5)$ & $188(17)$ & $436(39.4)$ & 2.25 & 1.184 \\
\hline To communicate with my lecturers & $107(9.7)$ & $375(33.8)$ & 195(17.6) & $431(38.9)$ & 2.20 & 1.619 \\
\hline Betting and online money making & $142(12.8)$ & $244(22)$ & $193(17.4)$ & $529(47.7)$ & 2.02 & 1.102 \\
\hline Online dating & $138(12.5)$ & $193(17.4)$ & $135(12.2)$ & $642(57.9)$ & 1.86 & 1.112 \\
\hline
\end{tabular}

Weighted mean $=2.62$

Table 4 revealed that social media tools are mainly used for group discussions and tutorials with course mates $(\bar{x}=3.22)$; they are also used to source for current materials for examinations and tests $(\bar{x}=3.21)$, used to check for updates on current research or new developments in my field of study $(\bar{x}=3.18)$, and the last two purposes were occasionally for betting or online money making $(\bar{x}=2.02)$ and online dating $(\bar{x}=1.86)$. The inference drawn from this is that, undergraduates use social media platforms tools to connect with other classroom mates, track a 
word or phrase, attend lectures remotely, learn personally, find scientific research papers, create apps, provide direct communication with instructors, brainstorm and share knowledge among others.

\section{Conclusion and Recommendations}

The study concludes that the undergraduates in the selected universities in Ogun state have knowledge of social media and they make use of them. Also many of these students use the sites for the purpose of group discussions and tutorials, maintaining social contacts with friends/relatives and they also use them for sourcing current materials for examinations and tests. However, it was discovered that many of the students spend lots of time visiting the social media platforms. No wonder, a significant percentage of the students claimed that using social media reduces the time they spend studying, and some are distracted in the classroom.

Based on these findings, the following recommendations were made:

- The students should be sensitised on the purposive use of social media for their education.

- Students should be made to understand that overindulgence in social media is addictive and time wasting hence exercising self-control as early as possible.

- Time-off software should be installed to control social media use by students.

- Parents can also advice and monitor their wards especially teens to limit the time they spend on socialnetworking. They should rather use those hours to read other academic books that will help to improvetheir knowledge.

- Lecturers should help the students to make meaningful use of social networking sites by incorporatingthem into their lessons.

- Students should be advised on the dangers of getting addicted to social networking

\section{References}

Adebayo,O. A.(2015). Awareness and usage of social networking sites by students of library and information science: The case of federal polytechnic, Offa, Nigeria. Information and Knowledge Management, 5(12), $116-121$

Ahmed, I.andQazi, F.T. (2011). A look out for academic impacts of social networking sites (SNSs): A student based perspective. African Journal of business management,5(12), 5022-5031

Balaban-Sali, J. (2012). New media literacies of Communication students.Contemporary Educational Technology, $3(4), 265-277$.

Chen, R., \& Sakamoto, Y. (2013). Perspective matters: Sharing of crisis information in social media. Proceedings of the Annual Hawaii International Conference on System Sciences 2033-2041.

Flad, K. (2010). The influence of social networking participation on student academic performance across gender lines.Counsellor Education Master's thesis. Paper 31: 1-58Retrieved from http://digitalcommons.brockport.edu/edc_theses/31

Lewis, B. K. (2009). Social media and strategic communication: Attitudes and perceptions among college students. Public Relations Journal, 4, 1-23.

Ma, W. K.\& Chan, A. (2014). Knowledge sharing and social media: Altruism, perceived online attachment motivation, and perceived online relationship commitment. Computers in Human Behavior, 39, 5158.https://doi.org/10.1016/j.chb.2014.06.015

Mehmood, S. and Taswir, T. (2013). The effects of social networking sites on the academic performance of students in college of applied science, Nizwa, Oman. International Journal of Arts and Commerce,2(1), 111-123

Mozee, S. (2013). The Impact of social media use on academic performance at one urban university: A pilot study, urban education: Online Journal of Rural and Urban Research, 2(1), 1-10.

Pempek, T. A., Yermolayeva, Y. A., \& Calvert, S. L. (2009). College students' social networking experiences on Facebook. Journal of Applied Developmental Psychology, 30(3), 227238.https://doi.org/10.1016/j.appdev.2008.12.010

Quan-Haase, A., \& Young, A. L. (2010). Uses and gratifications of social media: A comparison of Facebook and instant messaging. Bulletin of Science, Technology \& Society, 30(5), 350361.https://doi.org/10.1177/0270467610380009

Rubina, B. and Shakeel, A.K. (2012). Application of social media in marketing of library and information services: A case study from Pakistan. Webology,9(1), Article 93. Retrieved from http://www.webology.org/2012/v9n1/a93.htm

Sponcil, M., \&Gitimu, P. (2013). Use of social media by college students: Relationship to communication and self-concept. Journal of Technology Research, 4, 1-14.

Trend, D. (2010). The End of Reading: From Gutenberg to Grand Theft Auto. New York: Peter Lang.

Yoo, S. J., \& Kim, S. (2013). How and why college students use Web 2.0 applications: The role of social media in formal and informal learning. International Journal of Web Based Communities, 9(2), 174187.https://doi.org/10.1504/IJWBC.2013.053242 